\title{
OBSERVATIONS ON CHYTRIDIACEOUS PARASITES OF PHANEROGAMS. XIV. PHYSODERMA CALAMI ${ }^{1,2}$
}

\section{F. K. Sparrow}

Department of Botany, University of Michigan, Ann Arbor, Michigan

\section{A B S T R A C T}

\begin{abstract}
Physoderma calami, a chytrid (Phycomycetes), has not been studied or apparently even collected in Europe since 1895 and has never been recorded in this hemisphere. Material widely distributed in herbaria indicated it was a Physoderma but no details save color, shape, and size of resting spores were known. A study of living material from Vermont indicates resting spore germination occurs by dehiscence of a lid and production of a sporangium with zoospores. The latter may form either an epibiotic or "ephemeral" sporangial stage and zoospores, or an endobiotic one, with extensive polycentric thallus bearing turbinate cells along the rhizoids, and, as outgrowths of these turbinate cells, straw-colored, thick-walled resting spores. The latter stage produces dark-brown spots on infected parts of the host.
\end{abstract}

In November, 1895, K. W. Krieger issued the twenty-second fascicle of his "Fungi saxonici," numbers 1051-1100. Included was a fungus, No. 1081, Physoderma calami n. sp., termed rare, on leaves of Acorus calamus, first collected in a pond "auf der Ebenheit bei Königstein" in 1891, and subsequently in 1892 and 1895 . It was distributed in Sydow "Phycomyceten et Protomyceten" No. 175 , as collected in August, 1896, and finally in Sydow's "Mycotheca germanica" \#780 as collected in July, 1908. All these were from the same site. It is apparent, however, from the herbarium of J. Schroeter ${ }^{3}$ that this investigator had found a Physoderma on Acorus at "Lanisch bei Breslau" in Silesia, on 8 August 1886, a collection not heretofore recorded in the literature or found in other herbaria examined by me. Although correctly labelled a Physoderma, no species name was appended. A description of Krieger's species, confined, as was usual, to data on resting spores and host symptoms, was published in Hedwigia in December, 1896. So far as this writer can determine, Krieger's collection from one spot in Saxony and Schroeter's from Silesia represent the European material known of this species. None seems to have been reported from the New World. The fungi in the 3 aforementioned, widely distributed exsiccata are clearly species of Physoderma, as evidenced by their ellipsoidal, flattened resting spores, although Karling (1950), in speaking of $P$. calami and $P$. allii, states that "both are so imperfectly known that their validity is highly questionable."

1 Received for publication March 23, 1964.

Acknowledgment is made to the National Science Foundation for support of this investigation. I wish further to acknowledge my indebtedness to the late Dr. R. M. Johns and to Dr. P. W. Cook for obtaining the material of $P$. calami, and to Joyce E. Griffin for her assistance.

${ }^{2}$ Contribution No. 1154, Department of Botany, Univ. of Mich.

${ }^{3}$ I wish to thank the Head, Department of Plant Systematics for loan of material from the Herbarium, Inst. Bot. Univ. Wratislavensis.
In the 2 localities, the fungus was associated on the Acorus leaf with Stagonospora calami Bres. which, in contrast to the Physoderma, produced large, narrowly ellipsoidal blackish areas $1 \mathrm{~cm}$ or more in length. Krieger's material was only on browned leaves, not living ones, and formed slightly protruding, round or oblong brown spots $\frac{1}{2}-1 \frac{1}{2} \mathrm{~mm}$ in diameter. The resting spores were numerous in the leaf cells, straw-colored, ellipsoidal and slightly flattened on one face and 14.4$20.8 \times 11.2-16 \mu$.

In the autumn of 1962 , a good dried collection of bright-green leaves of Acorus calamus infected by both Stagonospora and Physoderma was sent me by the late R. M. Johns and by P'. W. Cook from Vermont. All indications from the nature of host lesions, resting spores, etc. were that this was the same Physoderma known hitherto only from 2 European sites. Further viable material was obtained through the kindness of Dr. Cook this past fall, and it is on this collection that the following account is based.

Resting spores were scraped from host pustules into triple-distilled water in shallow watch glasses and left in a constant-light and -temperature room at $23.5 \mathrm{C} 9$ in. from a battery of cool-white fluorescent lamps delivering at that distance 460 $\mathrm{ft}-\mathrm{c}$. After $48 \mathrm{hr}$, resting spores which were to germinate developed a delicate line of dehiscence which delimited the future operculum. At this time, too, the contents lost the large central vacuole characteristic of the mature resting spore and became coarsely and irregularly granular. As germination proceeded, a broad, slightly convex operculum, $10-12 \mu$ in diameter, was very gradually thrown aside or carried away from the body of the spore by an imperceptibly elongating, broad, finger-like, thin-walled endosporangium (liig. 1,2). When this protrusion from the spore nearly equalled the latter in length, a prominent, broad, discharge papilla began to form at its narrower, distal end (Fig. 3, 4). Meanwhile, the endosporangium contents passed through a series 
of changes, including the characteristic "ring stage" (Fig. 4), exactly similar to that described in another paper in detail (Sparrow, Griffin, and Johns, 1961). Eventually, 40 or more equally spaced, like-sized, hyaline globules resting in a clear matrix of endosporangial cytoplasm indicated zoospore discharge was imminent (Fig. 5).

At the moment of discharge, the papilla suddenly expands, drawing out the first of the zoospores, and continues to do so until it fades into the surrounding medium (Fig. 6-8). The zoospores are at this time continuing to emerge, individually inert, but moving as a closely cohesive mass. This process occupies only a few seconds and when all have emerged from the sporangium, flagellar motility is initiated and the individual zoospores swim away. Prior to, and during, discharge, individual spore bodies are difficult to delimit although occasionally visible. The single posterium flagellum of each spore is usually first seen as the zoospores pull away from one another just before swimming away. These r.s. ${ }^{4}$ zoospores are at first spherical, approximately $5-6 \mu$ in diameter, but as they begin to swim, they become ovate. There is a single, colorless, somewhat eccentric globule $2.5 \mu$ in diameter in the spore body (rig. 9).

It will be recalled that in this genus of chytrids 2 kinds of thalli are produced by some species. ${ }^{5}$ The extensive endobiotic stage, visible macroscopically as pustules, has been alluded to earlier. There may also be formed a microscopic, epibiotic stage, scarcely, if at all, visible and completely separate from the other.

In Physoderma calami, as in the parasite of Agropyron repens (Sparrow et al., 1961) and $P$. maculare (Sparrow, 1964), the r. s. zoospore can settle down on the surface of the mature leaf tissue or seedling and give rise either to the epi(Fig. 11) or endobiotic (Fig. 25) stages.

Once encysted, the zoospore which will form the epibiotic sporangium soon produces a short infection tube which gains entrance into the epidermal cell of the host. There it eventually gives rise distally to a group of stubby haustorium-like elements. In contrast to other species this endobiotic part of the developing thallus, which is confined to a single cell, is very difficult to observe since it is usually covered with host cell debris (Fig. 14).

Meanwhile, unilateral elongation of the cyst body is initiated (Fig. 10) and followed by bilateral elongation and general expansion. As in Physoderma butomi (Büsgen, 1887) and certain other species, a portion of the cyst of the zoospore, which is little if at all enlarged, is pushed laterally or upward by the steadily enlarging sporangial rudiment and persists as a sharply defined hemi-

\footnotetext{
${ }^{4}$ Zoospores from resting spores. the whole developmental cycle, including germination of the newly formed resting spores, takes place within 17 days in the laboratory.
}

sphere of wall material $10 \mu$ in diameter (Fig. 14, 26a).

The contents of the rudiment also undergo change. The globule of the encysted zoospore fragments and the initially clear contents become granular (Fig. 10). As the rudiment increases in size, it becomes more densely granular and eventually the "ring-stage" just preceding final maturity is reached (Fig. 16a). There then follows, coincidentally with formation of a discharge papilla usually at one end of the sporangium, a gradual "clearing" of the cytoplasm and organization of the regularly spaced zoospore globules.

At maturity, this epibiotic sporangium is typically strongly tubular and, when uncrowded (Fig. 16), of considerable size (up to $70 \times 10$ $12 \mu)$. Other sporangia are broader, truncate and generally more massive, whereas a few (Fig. 12, 13) are small, thin-walled objects. These extreme variations may be due possibly to the amounts of nutritive available in the parasitized host cell. Less tubular sporangia, often formed in great numbers on the epidermis (Fig. 17), may be $45-65 \times 15-$ $18 \mu$.

As the sporangium attains its maximum size, a papilla develops at one end which suddenly swells up and deliquesces as the zoospores emerge. In contrast to epibiotic sporangia in all other species of the genus, 2 papillae are sometimes formed, 1 at either narrow end (Fig. 19). At the moment of discharge, both swell and deliquesce, although in the cases observed the majority of the zoospores emerged from one orifice and only a few from the other (Fig. 20, 21). The zoospores, once outside, quickly become motile and swim away (Fig. 21, $22)$. They are globular or slightly ovate when in motion, $4 \mu$ in diameter, with a colorless, slightly basal globule $2 \mu$ in diameter and a single posterior flagellum (Fig. 23). Thus, they are slightly smaller than those from germinated resting spores. Sporangia which are once internally proliferous have been observed (Fig. 15, 16). A zoospore-like structure initiates growth of the new sporangium (Fig. 16, 18, 24).

Resting-spore zoospores may also give rise to the endobiotic stage after settling down on the host epidermis of a mature structure (leaf) or of a seedling. After penetration of the host has been accomplished by a tube from the encysted zoospore body, there is formed at its end the primary turbinate cell 5-6 $6 \times 11-14 \mu$ which may become divided into $2-3$ cells (Fig. 25, 26b). From the part opposite the point of attachment to the infection tube, a delicate, unbranched rhizoid emerges which may continue to elongate and pass into an adjacent cell or form another turbinate cell immediately. Subsequent rhizoid extension and turbinate-cell formation carry the infection from cell to cell of the Acorus.

Resting spores originate as in other species of the genus, i.e., as small, spherical or slightly ellipsoidal bodies at the tip of a tubular lateral outgrowth from 1 cell of a secondary turbinate 

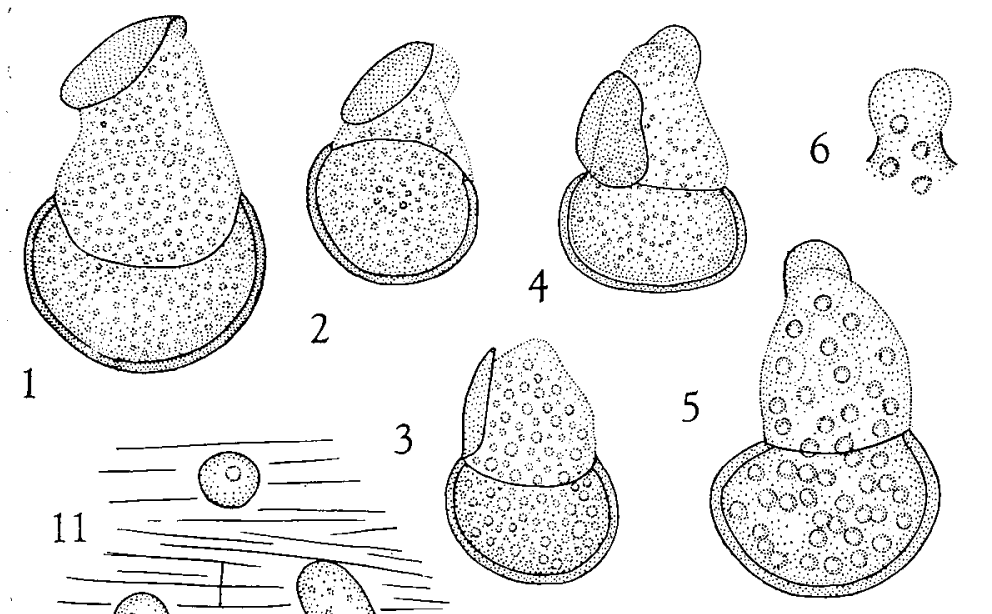

8
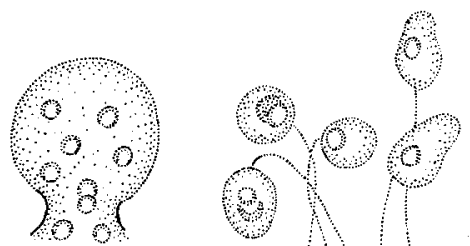

2

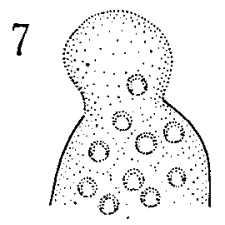

अ,

9

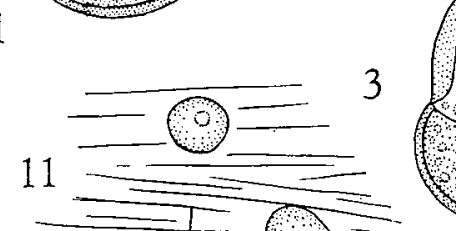

$=1$
$=10$
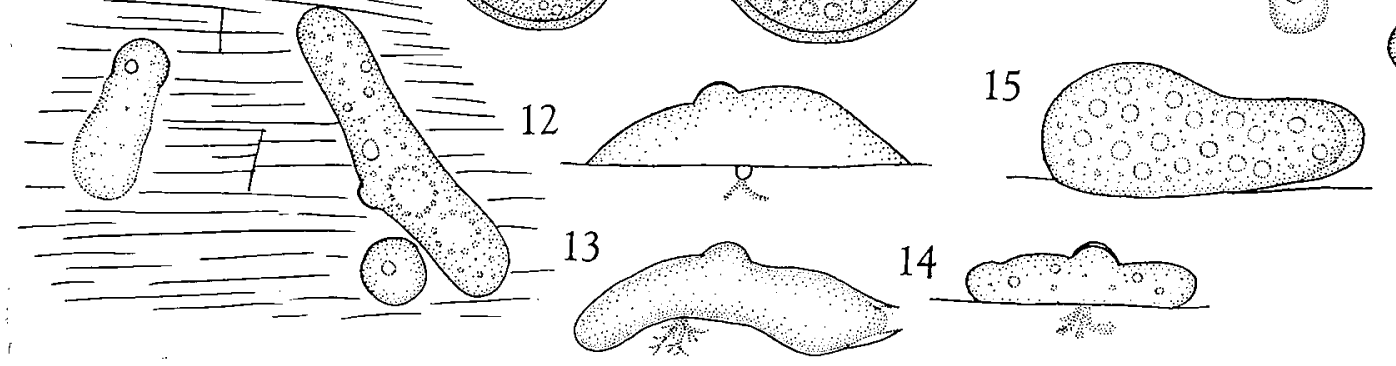

$1 4 \longdiv { 0 }$

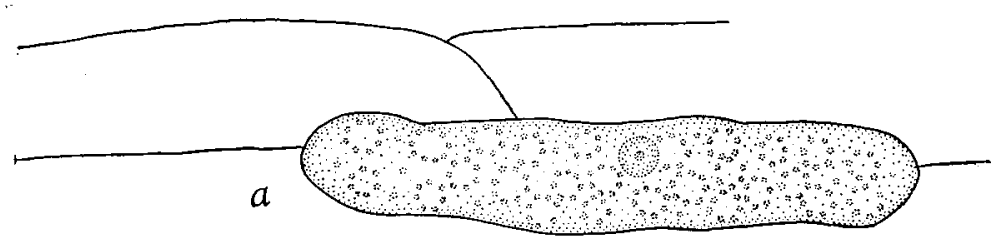

16

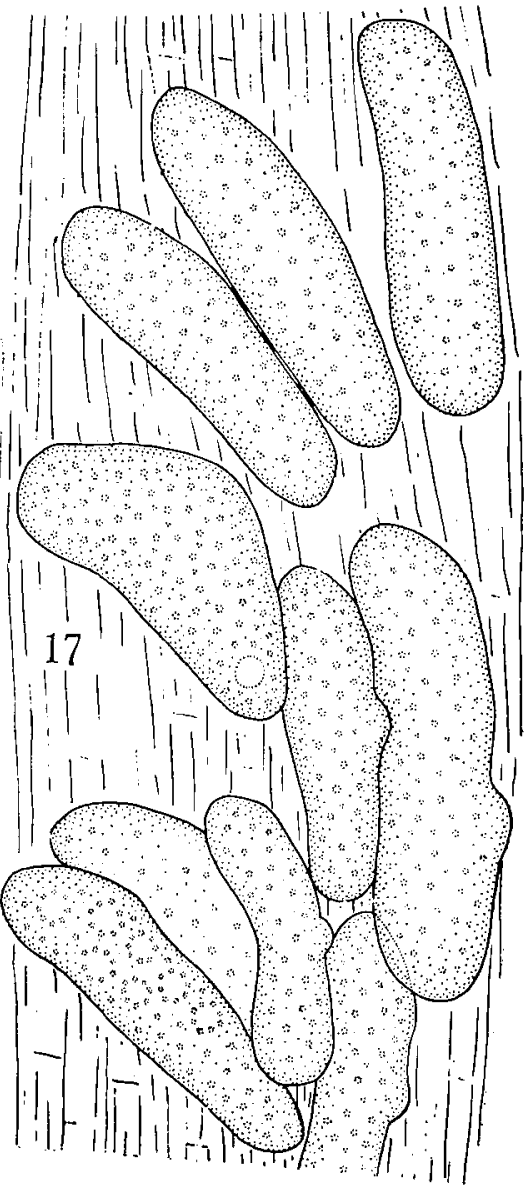

See page 962 for caption. 

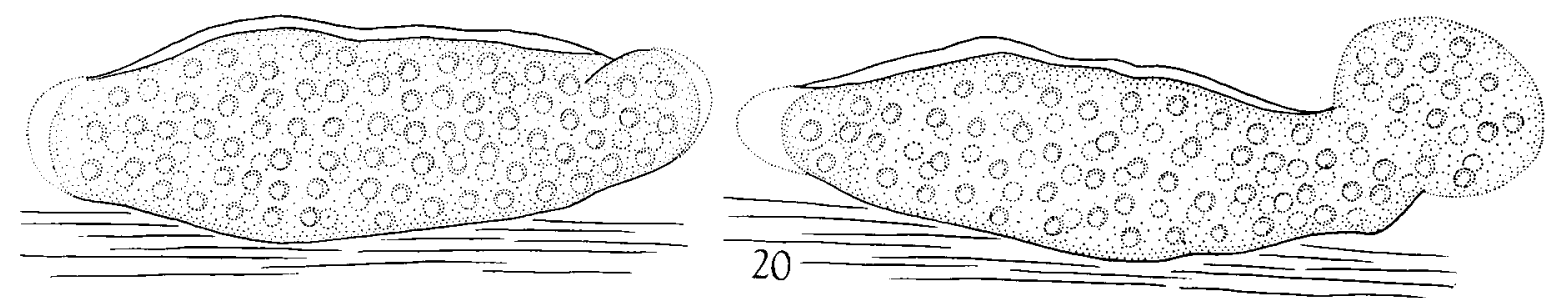

19

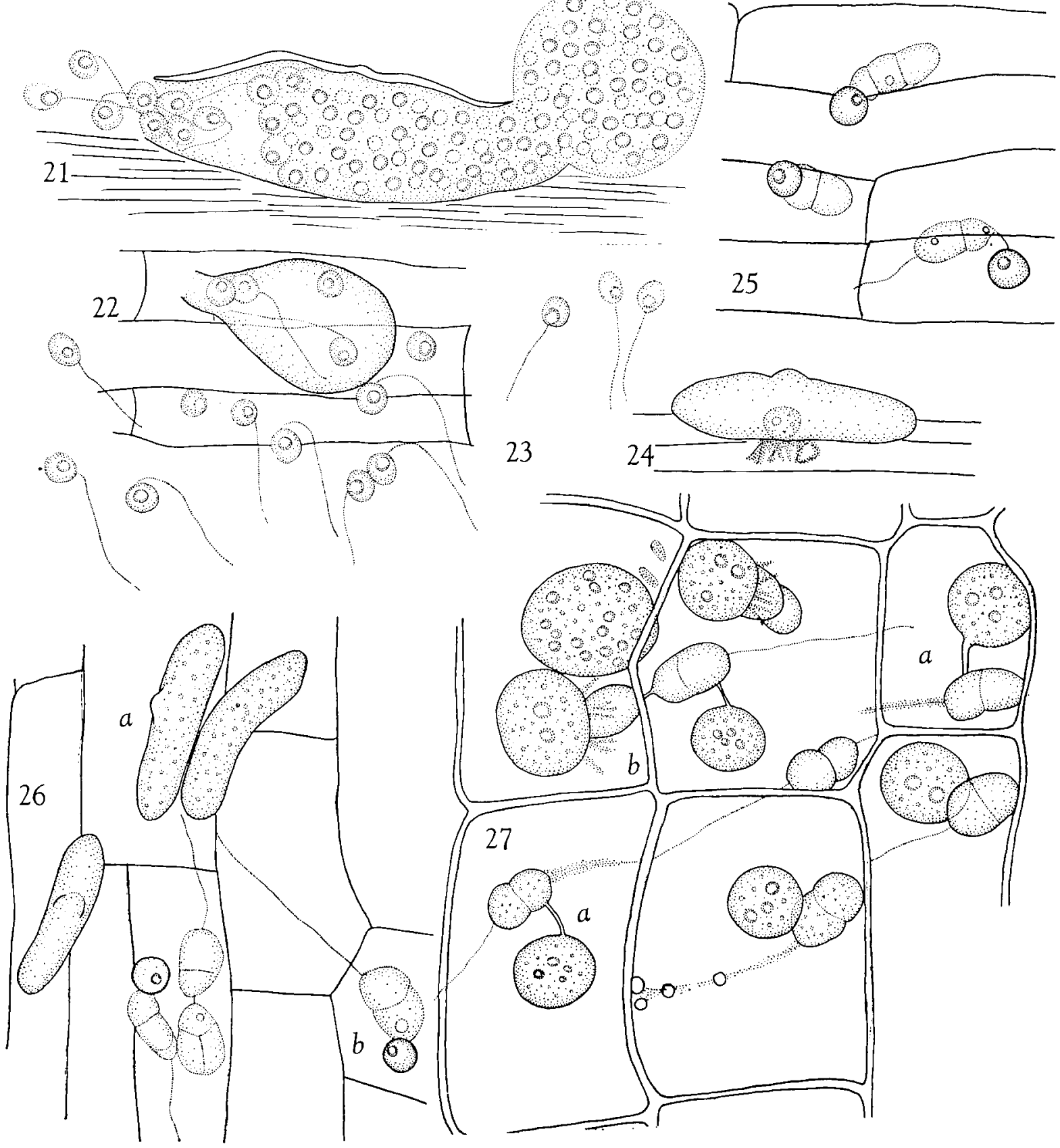

See page 962 for caption. 
TABLE 1. Measurements of resting spores of Physoderma calami on Acorus calamus from 3 different collections

\begin{tabular}{lccc}
\hline \hline & Krieger $^{\mathbf{a}}$ & Schroeter $^{\mathbf{a}}$ & Johns and Cook $^{\mathbf{b}}$ \\
\hline Mean long axis & $17.4 \mu$ & $17.4 \mu$ & $17.3 \mu$ \\
Mean short axis & $13.5 \mu$ & $14.5 \mu$ & $14.1 \mu$ \\
Largest spore & $20.8 \times 16 \mu$ & $20.8 \times 17.6 \mu$ & $22.4 \times 16 \mu$ \\
Smallest spore & $14.4 \times 9.6 \mu$ & $14.4 \times 11.2 \mu$ & $12.8 \times 9.6 \mu$ \\
\hline
\end{tabular}

s 50 spores measured.

b 100 spores measured.

cell (Fig. 27a). This rudiment steadily increases in size and may bear a few antler-like, delicate haustorial structures (Fig. 27b). Resting spores form very soon in this species, and 5 days after original exposure of Acorus plants to restingspore zoospores, nearly mature ones may be found. As the spores approach maturity, a distinctly thickened wall envelops them which at maturity is thick and pale amber in color. The contents of growing spores bear many unlikesized refractive globules. As the spore becomes walled, these globules assume a more uniform size and become dispersed around a large, central vacuole-like structure.

Mature resting spores are straw-colored, ellipsoidal and slightly flattened on 1 face, with a wall approximately $1.5 \mu$ thick. Measurements from the 3 collections are remarkably uniform as may be seen in Table 1.

It can be seen that there is little difference between the spores in the means of their axes. The Vermont material has both the largest and smallest spores, but this may be due to the larger sample taken.

A description of the species based on the living material from Vermont follows. As regards host symptoms and resting spores, no significant differences from any of the European material are evident.

Physoderma calami Krieger, amend.-Epibiotic sporangium tubular or less often broadly slipper- shaped and asymmetric, with blunt apices, lying with its long axis parallel to the surface of the host, a slightly expanded portion of the zoospore cyst, $10 \mu$ in diameter, usually persistent in the mid-region of the body, variable in size, up to $90 \times 15 \mu$ when tubular, less tubular ones up to $65 \times 20 \mu$, smaller ones formed by internal proliferation; rhizoidal system difficult to observe, arising from a small swelling beneath the sporangium, composed of inconspicuous, short, branched elements; zoospores $4 \mu$ in diameter, spherical at first, becoming ovate when swimming, with a colorless, $2 \mu$ spherical globule and $15 \mu$-long posterior flagellum. Endobiotic system arising from a 1-2 transversely septate primary turbinate cell $11-14 \mu$ long by $5-6 \mu$ wide; rhizo:ds unbranched, with secondary turbinate cells up to $10 \times 8 \mu$, extending from cell-to-cell within the host; resting spore arising at the tip of a delicate, tubular, lateral outgrowth of a segment of a secondary turbinate cell, sometimes bearing a few antler-like, delicate outgrowths of limited extent; mature resting spores ellipsoidal with 1 surface slightly flattened, 12.8-22.4 $\times$ 9.6-16 $\mu$ (mean $13.5 \times 17.4 \mu)$; wall approximately $1.5 \mu$ thick, apparently unpitted; upon germination dehiscing by a lid $10-12 \mu$ in diameter from the flattened surface, the subsequently developed protruding sporangium broadly conical, $15 \times 7-12 \mu-$ $20 \times 7-15 \mu$ with a broad apical discharge papilla, zoospores spherical at first, $5-6 \mu$ in diameter, becoming somewhat ovate when swimming, with

Fig. 1-27. Physoderma calami, a parasite of Acorus calamus, $\times 825$.-Fig. 1-8. Germination of resting spores of $P$ hysoderma calami.-Fig. 1, 2. Dehiscence of cap and formation of endosporangium.-Fig. 3. Beginning of formation of apical discharge papilla; also visible in Fig. 2.-Fig. 4. Papilla mature, contents in "ring stage."-Fig. 5. Endosporangium immediately prior to discharge.-Fig. 6-8. Stages in swelling of discharge papilla.-Fig. 9. IR. s. zoospores, some showing nuclear cap.-Fig. 10. Encysted r. s. zoospores, one of which has initiated unilateral elongation of body.-Fig. 11. Surface of host seedling showing various stages of epibiotic sporangium formation from r. s. zoospores.-Fig. 12-13. Small mature or proliferating sporangia.-Fig. 14. Young epibiotic sporangium showing portion of cyst of zoospore as apical protrusion.-Fig. 15. Nearly mature secondary proliferated sporangium.-Fig. 16. Surface of host showing at "a," epibiotic sporangium with contents in "ring stage." Other sporangia have discharged; one has proliferated internally. Tubular sporangia typical of those formed under uncrowded conditions.-Fig. 17. Portion of host with more robust sporangia crowded on surface.-Fig. 18. Tubular sporangium with exit pores at either end and new sporangium starting to form internally.-Fig. 19-21. Stages in discharge of zoospores from both apices of a tubular sporangium. In Fig. 21 , a few spores only are making use of 1 pore.-Fig. 22. Broader sporangium which has just discharged its zoospores.Fig. 23. Several zoospores.-Fig. 24. Empty sporangium showing vague outlines of rhizoidal system which is mostly obscured by host material.-Fig. 25. Three primary turbinate organs within host, attached to r. s. zoospore cysts on outside of host.-Fig. 26. At " $a$," young epibiotic sporangia; at " $b$ " and to left of it, young endobiotic thalli with attached external cysts of r. s. zoospores. Both stages have been produced from the same lot of r. s. zoospores.-Fig. 27. Endobiotic system showing at " $a$ " rudiment of a resting spore forming at the tip of a lateral outgrowth from 1 cell of a turbinate organ. At "b," the outgrowth is hidden by developing spore; haustorial processes visible on spore rudiment. 
a colorless $2.5 \mu$-diameter globule and $20 \mu$-long posterior flagellum.

Parasitic on leaves of Acorus calamus L., forming slightly protruding, round or oblong brown spots $0.5-1.5 \times 0.5 \mathrm{~mm}$; Germany, Poland, United States.

\section{LITERATURE CI'TED}

Büscies, M. 1887. Beitrag zur Kenntnis der Cladochytrien. Cohn. Beitr. Biol. Pflanzen. 4: 269-283. Pl. 15.
Karling, J. S. 1950. The genus Physoderma (Chytridiales). Lloydia 13: 29-71.

KrIEger, (K.) W. 1896. Fungi saxonici exsiccati 1. Hedwigia 35: (143)-(145).

Sparrow, F. K. 1964. Observations on chytridiaceous parasites of Phanerogams. XIII. Physoderma maculare Wallroth. Arch. Mikrobiol. 48: 136-149, Fig. 1-33. , J. E. GRIFFIn, AND IR. M. Johns. 1961. Observations on chytridiaceous parasites of Phanerogams. XI. A Physoderma on Agropyron repens. Amer. Jour. Bot. 48: 850-858. Fig. 1-53.

Amcr. Jour. Bot. 51(9): 963-975. 1964.

\title{
DIFFUSION RESISTANCE IN LEAVES AS RELATED TO THEIR STOMATAL ANATOMY AND MICRO-STRUCTURE ${ }^{1}$
}

\author{
Richard Lee² and David M. Gates
}

Institute of Arctic and Alpine Research, University of Colorado, Boulder, Colorado

\begin{abstract}
Transpiration from a plant leaf depends upon the water vapor pressure gradient between the substomatal cavity and the free air beyond the leaf. Transpiration also depends inversely on the resistance of the diffusion pathway through the substomatal cavity, stomate, and surface boundary layer. The value of the diffusion resistance is derived mathematically for Zebrina pendula, Medicago sativa, and Pinus resinosa. The vapor pressure gradient depends on the leaf temperature and therefore is related to the energy budget of the leaf. The exact solution of the diffusion equation is described and limiting examples discussed. The so-called "diameter law" is a special case which is distinctly limited in its application.
\end{abstract}

I'HE PHYSICAL-PHYSIOLOGICAL transpiration phenomenon in plants presents a many-faceted problem with which it is impossible to deal in a minor treatise. Historical progress is recorded in a voluminous literature. Whether empirical or theoretical, qualitative or quantitative, the most enlightening results many times have stemmed from studies focused upon a single problem facet. The prescnt paper is concerned chiefly with the simple mechanical resistances to water loss from leaves in the vapor phase through intercellular, substomatal, and stomatal mechanisms.

A possible difficulty of diffusion theory as applied to leaf systems may stem not only from an improper description of the stomatal dimensions, but also because of physiological reactions at the evaporating surface-the mesophyll walls (Boon-Long, 1941; Klemm, 1956; and Shimshi, 1963). A quantitative explanation of the latter may require a detailed understanding of the water relations of living cells, and a much more sophisticated approach (cf. Dainty, 1963).

1 Received for publication April 2, 1964.

This research was supported by a grant from the National Science Foundation.

2 Now at U. S. Department of Agriculture, Forest Service, liocky Mountain Forest and Range Experiment Station, Arizona State University, Tempe, Arizona.
HISTORY OF SUBJECT-The pertinent basic evaporation laws were derived by Stefan (1881), but often have been misinterpreted. Proceeding from heat transfer theory and electrostatics, he derived the so-called "diameter law" for the diffusion in unit time of a volume of vapor, $V$, from a surface of radius, $s$, given by:

$$
V=4 k s \ln \frac{P-p_{0}}{P-p_{1}}
$$

where $k$ is the diffusion coefficient, $P$ the atmospheric pressure, and $p_{1}$ and $p_{0}$ the vapor pressure at the surface and at some great distance from the surface respectively. Stefan is often misquoted as predicting diameter proportionality for evaporation from a water surface through a tube, and the "diameter law" often leads to the false impression that perforated septa may actually increase vapor losses from water surfaces which they cover. In actual fact Stefan's analysis applied only to a liquid surface in the midst of a coincident, impermeable, non-evaporating plane of infinite dimensions. Further discussion of the "diameter law" will be made under "critique of diameter law."

Early attempts to relate basic evaporation laws to diffusion from leaves centered around the 